\title{
Methodology of calculation and structural analysis of Journal Impact Factor based on the Web of Science: A case study of Nature
}

\author{
Liu Xue-Li, Gai Shuang-Shuang ${ }^{*}$ and Zhang Shi-Le \\ Periodicals Publishing House and Henan Research Center for Science Journals, \\ Xinxiang Medical University, Xinxiang Henan Province, P.R. CHINA \\ e-mail: *hrcsj2009@163.com (corresponding author)
}

\begin{abstract}
In this paper, we take Nature as a case study to present a new method for calculating and analyzing the structure of the Impact Factor (IF) using the Web of Science (WoS) database and the definition of IF. We calculated Nature's IF for 2013 using data retrieved on 21 March 2014 from the WoS database and comprehensively analyzed its structural features, thereby identifying the contributions to Nature's IF for 2013 of different document types, highly cited papers, highly cited authors, different institutions, and different countries and regions. The results show: (a) the calculated value of Nature's IF for 2013 is 41.002 according to data retrieved in March of 2014; (b) two types of document, article and review, made prominent contributions to Nature's IF for 2013, with contribution values of 35.338 and 3.179, respectively; (c) the institutions that made the greatest contributions to Nature's IF for 2013 are mainly located in the USA and England, with the first three highly cited institutions being Harvard University, Stanford University, and Washington University; (d) the contributions of different countries and regions to Nature's IF for 2013 differ greatly, with the combined contribution rate of the USA and England being 70.4 percent.
\end{abstract}

Keywords: Nature; Journal studies; Impact factor; Structural analysis; Bibliometrics

\section{INTRODUCTION}

Nature, the world's most highly cited interdisciplinary science journal, is published by the Nature Publishing Group, an independent British commercial publisher, and is viewed as the publisher's "flagship". Not only has it been recognized by Elsevier as the most influential journal, but it also enjoys widespread influence and high prestige internationally (Pai 2009). In China, Nature is attracting increasing attention among the academia; especially in recent years, where many universities and research institutions have established incentive policies to encourage researchers to publish more papers in Nature. For example, China Agricultural University, South China Normal University, and Zhejiang SciTech University each award one million yuan (RMB) per paper published in Nature. The Xinxiang Medical University has recently declared an award of one million yuan per paper published in Nature or any of its series having an impact factor (IF) of 20 or greater. Yangzhou University and Nanjing University award 0.5 million and 0.3 million yuan per 
paper respectively; Nankai University, Harbin Institute of Technology, and Nanjing University of Aeronautics and Astronautics have announced an award of 0.1 million yuan per paper published in Nature. It is also widely recognized that Nature is not only used for determining monetary awards in the Chinese scientific evaluation system, but it is also commonly used in the selection of academicians to the Chinese Academy of Sciences and the Chinese Academy of Engineering.

Garfield (1955), first proposed the term IF in his paper published in Science, referring to citations to articles. Later Garfield and Sher $(1963)$ proposed IF as an indicator for evaluating the academic impact of journals in 1963, after which IF was applied to assist the selection of source journals in the Science Citation Index (SCl) database. With the launching of the Journal Citation Reports (JCR) in 1976, the IF has been viewed as an important journal evaluation indicator and has increasingly gained wider attention and application (Betz 2014; Campanario 2011a; Servaes 2014). However, with the increasingly widespread use for journal evaluation, the IF exposed several defects and caused much abuse and misuses. For example, it is not only used in measuring the research performance of scientists (Holden et al. 2006; Shao and Shen 2012), institutions (Kim and Kim 2000; Liu 2012), and countries (Ugolini and Casilli 2003; Jokic 2003), but also in administering academic appointments, evaluating grant applications, and allocating other financial support for research programs (Adam 2002). Knowing the IF of certain journals in advance can not only help authors in selecting journals to which to submit their work, but also help editors take steps to increase their respective journals' IF accordingly. Thus, it is important to understand the methodology of the calculation and the structure of the journal IF.

There have been few studies performing a prediction or structural analysis of the journal IF. $\mathrm{Wu}, \mathrm{Fu}$ and Rousseau (2008) discussed two methods for predicting IF in detail and explained why it was useful to derive one's own journal IF. Kovacic (2004) analyzed the structure of the $2003 \mathrm{IF}$ for the Croatian Medical Journal (CMJ) and studied the effect of different kinds of citation on the IF of this journal. However, she only studied the contribution of article type to CMJ's IF in the structural analysis. Campanario et al. (2006) studied the structure of the IF of academic journals based on a calculation of the fraction of citations that contribute to the IF of a given journal. However, he only studied the structure of citations and papers highly cited by the editorial board members. The limitation in the scope of investigation calls for significant analysis. Thus, it is still of great significance to analyze the structure of the IF in more detail.

For this study, we selected Nature, a journal with high IF, as a case study to present a new approach to calculate and analyze the structure of the IF using the Web of Science (WoS) database (Andrade, Gonzalez-Jonte and Campanario 2009; Campanario 2011b). More importantly, taking Nature as an example, we not only show a method for calculating the journal IF but also make a full study of its structural features, including the contributions of different document types, highly cited papers, highly cited authors, different institutions, and different countries as well as regions.

\section{METHOD}

\section{Method of Computation for Nature's IF for 2013}

Document types published by Nature in 2011 and 2012 include articles, reviews, editorial materials, news items, book reviews, letters, corrections, and biographical items. Only articles and reviews are counted as citable items, which is the denominator in the formula 
for calculating a journal's IF (Simons 2008; Vanclay 2011). The numerator in the formula for the calculation of IF is the total number of citations of all documents in a given year. It is obvious that all document types can have an effect on the IF. We counted the number of papers published by Nature in 2011 and 2012 of each document type and their total citations in 2013 to calculate Nature's IF for 2013. The document retrieval date was 21 March 2014.

The IF for a given year is calculated by dividing the number of citations of items published in the previous two years by the number of citable items published in those same years. For example, the $2013 \mathrm{IF}$ is obtained as follows:

$$
\text { Impact Factor (2013) }=\frac{\text { Citations in } 2013 \text { of documents published in } 2011 \text { and } 2012}{\text { Citable items published in } 2011 \text { and } 2012}
$$

In our retrieved data, there were 1710 articles and reviews published by Nature from 2011 to 2012, and the total citations in 2013 of all documents were 70,114. By using the above formula we know that Nature's IF for 2013 is 41.002 . In addition, we calculated the IF for Nature for the years 2008 to 2012, and accordingly we retrieved Nature's actual IF from the JCR database for comparison. We then calculated the prediction error for each year. With a prediction error of 2.537 percent in 2012, the predicted value of Nature's IF for 2013 is 42.027. Detailed results are shown in Table 1.

Table 1: Calculated Value and Prediction Error of Nature's IF from 2008 to 2012

\begin{tabular}{cccccc}
\hline Year & $\begin{array}{c}\text { Citation } \\
\text { count* }\end{array}$ & $\begin{array}{c}\text { Number of } \\
\text { papers** }\end{array}$ & $\begin{array}{c}\text { Calculated } \\
\text { value }\end{array}$ & $\begin{array}{c}\text { Actual } \\
\text { value }\end{array}$ & Error rate \\
\hline 2012 & 64105 & 1703 & 37.642 & 38.597 & $2.537 \%$ \\
2011 & 63719 & 1728 & 36.87442 & 36.28 & $-1.612 \%$ \\
2010 & 63999 & 1773 & 36.09645 & 36.104 & $0.021 \%$ \\
2009 & 61053 & 1750 & 34.88743 & 34.48 & $-1.168 \%$ \\
2008 & 57088 & 1806 & 31.61019 & 31.434 & $-0.557 \%$ \\
\hline$*$ Citation count in the given year of papers published in the previous two years. \\
**Number of articles and reviews. Calculated value = (citation count)/(number of \\
papers); actual value is retrieved from the JCR database.
\end{tabular}

It is evident from Table 1 that although there are some errors between the calculated values for Nature's IF and its actual value, all errors remain under 2 percent, except in 2012. The error rate for 2010 is only 0.021 percent, which supports the credibility of this method of calculation for the IF. In addition, the calculated values of Nature's IF are higher than its actual values in 2008, 2009, and 2011. We deduce that the possible reasons may be due to:

(a) Errors that can take place when authors cite references because there are differences between the JCR database and the WoS database. For example, we searched the citations and the numbers of papers required to calculate the IF from 2008 to 2012 on the WoS database and the JCR database, and found that the only factor causing the difference between the calculated value of the IF and the actual value was the inconsistency in citation.

(b) Time factor: Individual papers can be cited after the JCR database has published the IF, which causes the number of citations used to calculate the IF from the WoS database is higher than that used in the JCR database. 
(c) Error handling and processing of the database: Our previous study showed that there were over 1,820,000 data processed by the WoS database in 2012 alone, so it would be difficult to avoid the possibility of mistakes in the journal citation data, which may lead in turn to errors in the calculation of the IF (Liu 2014a).

\section{Structural Features of Nature's IF for 2013}

\section{(a) Contribution of Different Document Types to Nature's IF for 2013}

Citations vary by document type. The types of documents published by Nature in 2011 and 2012 are as stated earlier. Table 2 details the number of papers of different document types and the contribution of each type to Nature's IF for 2013.

Table 2: Contribution of Different Document Types to Nature's IF for 2013

\begin{tabular}{|c|c|c|c|c|c|}
\hline Document type & $\begin{array}{c}\text { Number of } \\
\text { papers }\end{array}$ & $\begin{array}{l}\text { Citation } \\
\text { counts }\end{array}$ & $\begin{array}{c}\text { Citation } \\
\text { per paper }\end{array}$ & Contribution to IF & $\begin{array}{c}\text { Percentage of } \\
\text { contribution }\end{array}$ \\
\hline Article & 1639 & 60428 & 36.87 & 35.338 & $86.19 \%$ \\
\hline Review & 71 & 5436 & 76.56 & 3.179 & $7.75 \%$ \\
\hline Editorial material & 1703 & 2826 & 1.66 & 1.653 & $4.03 \%$ \\
\hline News item & 819 & 919 & 1.12 & 0.537 & $1.31 \%$ \\
\hline Letter & 560 & 443 & 0.79 & 0.259 & $0.63 \%$ \\
\hline Correction & 168 & 39 & 0.23 & 0.023 & $0.06 \%$ \\
\hline Book review & 241 & 19 & 0.08 & 0.011 & $0.03 \%$ \\
\hline Biographical item & 41 & 4 & 0.10 & 0.002 & $0.01 \%$ \\
\hline Total & 5242 & 70114 & 13.38 & 41.002 & $100 \%$ \\
\hline
\end{tabular}

Table 2 shows that articles and reviews received the highest citation counts among the eight document types. Articles made the greatest contribution to Nature's IF for 2013, as compared to other document types, contributing 86.19 percent of the total citations, followed by reviews (7.75 percent). Findings indicate that although the number of reviews is far lower than the number of articles, but the rate of citations per paper for reviews is more than twice than that for articles. Although the number of papers for editorial materials type is slightly higher than the number of articles, the citation rate of editorial materials is far lower than that for the articles. Other document types make little contribution to Nature's IF for 2013.

\section{(b) Contribution of Highly Cited Papers to Nature's IF for 2013}

We retrieved all documents published by Nature in 2011 and 2012 from the WoS database and selected the papers with citation counts in 2013 greater than 200 . We believe that the 18 most highly cited papers made a prominent contribution to Nature's IF for 2013.

From Table 3, we can see that there are nine highly cited papers published by Nature from the USA, four from England, two from Germany, and one each from Spain, Japan, and Belgium. In addition, the citation count of the paper about the human genome by $\mathrm{I}$. Dunham is much higher than that of the other papers, so it made the greatest contribution to Nature's IF for 2013, with a contribution value of 0.392 . 
Table 3: Contribution of Highly Cited Papers to Nature's IF for 2013

\begin{tabular}{|c|c|c|c|c|c|}
\hline $\begin{array}{c}\text { Corresponding } \\
\text { author }\end{array}$ & Institution* & Country & Document title & $\begin{array}{l}\text { Citation } \\
\text { counts** }\end{array}$ & $\begin{array}{c}\text { Contribution } \\
\text { to IF } \\
\end{array}$ \\
\hline Dunham, I & $\begin{array}{l}\text { European Bioinformatics } \\
\text { Institute }\end{array}$ & England & $\begin{array}{l}\text { An integrated encyclopedia of } \\
\text { DNA elements in the human } \\
\text { genome }\end{array}$ & 671 & 0.392 \\
\hline Perou, CM & $\begin{array}{l}\text { University of North } \\
\text { Carolina }\end{array}$ & USA & $\begin{array}{l}\text { Comprehensive molecular } \\
\text { portraits of human breast tumours }\end{array}$ & 359 & 0.210 \\
\hline Spellman, PT & $\begin{array}{l}\text { University of California, } \\
\text { Berkeley }\end{array}$ & USA & $\begin{array}{l}\text { Integrated genomic analyses of } \\
\text { ovarian carcinoma }\end{array}$ & 322 & 0.188 \\
\hline Bork, P & $\begin{array}{l}\text { European Molecular } \\
\text { Biology Laboratory } \\
\end{array}$ & Germany & $\begin{array}{l}\text { Enterotypes of the human gut } \\
\text { microbiome }\end{array}$ & 296 & 0.173 \\
\hline McVean, GA & University of Oxford & England & $\begin{array}{l}\text { An integrated map of genetic } \\
\text { variation from 1,092 human } \\
\text { genomes }\end{array}$ & 293 & 0.171 \\
\hline Kucherlapati, R & Harvard University & USA & $\begin{array}{l}\text { Comprehensive molecular } \\
\text { characterization of human colon } \\
\text { and rectal cancer }\end{array}$ & 269 & 0.157 \\
\hline Shen, JR & Okayama University & Japan & $\begin{array}{l}\text { Crystal structure of oxygen- } \\
\text { evolving photosystem II at a } \\
\text { resolution of } 1.9 \text { angstrom }\end{array}$ & 263 & 0.154 \\
\hline $\begin{array}{l}\text { Huttenhower, } \\
\text { C }\end{array}$ & Harvard University & USA & $\begin{array}{l}\text { Structure, function and diversity of } \\
\text { the healthy human microbiome }\end{array}$ & 261 & 0.153 \\
\hline Wolf, J & $\begin{array}{l}\text { Max Delbruck Center for } \\
\text { Molecular Medicine }\end{array}$ & Germany & $\begin{array}{l}\text { Global quantification of } \\
\text { mammalian gene expression } \\
\text { control }\end{array}$ & 248 & 0.145 \\
\hline Carmeliet, P & $\begin{array}{l}\text { Flanders Institute for } \\
\text { Biotechnology }\end{array}$ & Belgium & $\begin{array}{l}\text { Molecular mechanisms and } \\
\text { clinical applications of } \\
\text { angiogenesis }\end{array}$ & 245 & 0.143 \\
\hline Novoselov, KS & University of Manchester & England & A roadmap for graphene & 240 & 0.140 \\
\hline Kellis, M & $\begin{array}{l}\text { Broad Institute of MIT and } \\
\text { Harvard }\end{array}$ & USA & $\begin{array}{l}\text { Mapping and analysis of } \\
\text { chromatin state dynamics in nine } \\
\text { human cell types }\end{array}$ & 232 & 0.136 \\
\hline Kobilka, BK & Stanford University & USA & $\begin{array}{l}\text { Crystal structure of the beta( } 2) \\
\text { adrenergic receptor-Gs protein } \\
\text { complex }\end{array}$ & 223 & 0.130 \\
\hline Compston, A & University of Cambridge & England & $\begin{array}{l}\text { Genetic risk and a primary role for } \\
\text { cell-mediated immune } \\
\text { mechanisms in multiple sclerosis }\end{array}$ & 217 & 0.127 \\
\hline Guigo, R & $\begin{array}{l}\text { Center for Gene } \\
\text { Regulation }\end{array}$ & Spain & $\begin{array}{l}\text { Landscape of transcription in } \\
\text { human cells }\end{array}$ & 215 & 0.126 \\
\hline Garraway, LA & $\begin{array}{l}\text { Broad Institute of MIT and } \\
\text { Harvard }\end{array}$ & USA & $\begin{array}{l}\text { The Cancer Cell Line Encyclopedia } \\
\text { enables predictive modelling of } \\
\text { anticancer drug sensitivity }\end{array}$ & 208 & 0.122 \\
\hline Levine, B & $\begin{array}{l}\text { University of Texas } \\
\text { Southwestern Medical } \\
\text { Center }\end{array}$ & USA & $\begin{array}{l}\text { Autophagy in immunity and } \\
\text { inflammation }\end{array}$ & 203 & 0.119 \\
\hline Gordon, JI & Washington University & USA & $\begin{array}{l}\text { Human gut microbiome viewed } \\
\text { across age and geography }\end{array}$ & 203 & 0.119 \\
\hline
\end{tabular}

*First-named institution of the corresponding author. ${ }^{* *}$ Citation count in 2013.

(c) Contribution of Highly Cited Authors to Nature's IF for 2013

There are 5242 papers published in Nature during this period covered by the WoS 
database, and 3335 of them have a citation count of at least 1; therefore the citation rate for Nature papers published within those two years is 63.62 percent. Out of the 5242 papers, 2964 papers have ( 56.5 percent) at least one citation in 2013, meaning that only about half of all published papers have made a contribution to Nature's IF. The addresses of the corresponding authors of the 2964 papers are analysed to identify the contribution of highly cited authors to Nature's IF for 2013. The results are shown in Table 4.

Of the 20 highly cited corresponding authors, there are 13 authors from the USA, 3 from England, 2 from Germany, and 1 each from Japan and Belgium. The two authors who made the greatest contribution to Nature's IF for 2013 are I. Dunham, from the European Bioinformatics Institute in England, and B.K. Kobilka, from Stanford University in the USA, with contribution values of 0.392 and 0.364 , respectively. In addition, the two authors who published the most papers during these two years are M. Meyerson and T.R. Golub from the USA, with 14 and 10 papers, respectively, and contribution values of 0.185 and 0.149 , respectively.

Table 4: Contribution of Highly Cited Authors to Nature's IF for 2013

\begin{tabular}{|c|c|c|c|c|c|c|}
\hline Author* & Institution & Country & $\begin{array}{l}\text { Citation } \\
\text { counts }\end{array}$ & $\begin{array}{l}\text { Number of } \\
\text { papers }\end{array}$ & $\begin{array}{c}\text { Citation } \\
\text { per paper }\end{array}$ & $\begin{array}{c}\text { Contribution } \\
\text { to IF }\end{array}$ \\
\hline Dunham, I & European Bioinformatics Institute & England & 671 & 1 & 671.00 & 0.392 \\
\hline Kobilka, BK & Stanford University & USA & 623 & 9 & 69.22 & 0.364 \\
\hline Perou, CM & University of north Carolina & USA & 359 & 4 & 89.75 & 0.210 \\
\hline Spellman, PT & University of California, Berkeley & USA & 322 & 2 & 161.00 & 0.188 \\
\hline Meyerson, M & Broad Institute of MIT and Harvard & USA & 317 & 14 & 22.64 & 0.185 \\
\hline Gordon, JI & Washington University & USA & 313 & 4 & 78.25 & 0.183 \\
\hline Levine, B & Univ. of Texas Southwestern Med Cen. & USA & 307 & 3 & 102.33 & 0.180 \\
\hline Stevens, RC & Scripps research Institute & USA & 302 & 3 & 100.67 & 0.177 \\
\hline Bork, $\mathrm{P}$ & European Molecular Biology Lab & Germany & 296 & 2 & 148.00 & 0.173 \\
\hline McVean, GA & University of Oxford & England & 293 & 1 & 293.00 & 0.171 \\
\hline Kucherlapati, R & Harvard University & USA & 269 & 4 & 67.25 & 0.157 \\
\hline Ren, B & Ludwig Institute for Cancer Research & USA & 264 & 6 & 44.00 & 0.154 \\
\hline Shen, JR & Okayama University & Japan & 263 & 1 & 263.00 & 0.154 \\
\hline Huttenhower, C & Harvard University & USA & 261 & 2 & 130.50 & 0.153 \\
\hline Guttman, M & Broad Institute of MIT and Harvard & USA & 258 & 3 & 86.00 & 0.151 \\
\hline Golub, TR & Eli and Edythe L. Broad Institute & USA & 255 & 10 & 25.50 & 0.149 \\
\hline Carmeliet, $\mathrm{P}$ & Flanders Institute for Biotechnology & Belgium & 249 & 3 & 83.00 & 0.146 \\
\hline Wolf, J & Max Delbruck Cen. for Molecular Med. & Germany & 248 & 4 & 62.00 & 0.145 \\
\hline Novoselov, KS & University of Manchester & England & 240 & 1 & 240.00 & 0.140 \\
\hline Granier, S & Stanford University & USA & 235 & 2 & 117.50 & 0.137 \\
\hline
\end{tabular}

* The corresponding author.

(d) Contribution of Highly Cited Institutions to Nature's IF for 2013

We analyzed the first-named institutions of the corresponding authors of the 2964 papers and identified the first 20 highly cited institutions - those who made the greatest contribution to Nature's IF for 2013. The 20 highly cited institutions and their contributions are shown in Table 5.

There are 13 universities, 6 research institutes, and 1 research center among the first 20 highly cited institutions. In other words, the institutions making the most prominent contribution to Nature's IF for 2013 are primarily research organizations and universities. Moreover, the first five institutions making the greatest contribution are universities. The results reveal that universities are important headstream for research output. In addition, 
all of the first 20 highly cited institutions are located in the USA (16) and England (4).

Table 5: Contribution of Highly Cited Institutions to Nature's IF for 2013

\begin{tabular}{llrr}
\hline Institution & Country & $\begin{array}{c}\text { Citation } \\
\text { counts }\end{array}$ & $\begin{array}{c}\text { Contribution to } \\
\text { IF }\end{array}$ \\
\hline Harvard University & USA & 3242 & 1.896 \\
Stanford University & USA & 2536 & 1.483 \\
Washington University & USA & 2103 & 1.230 \\
University of California, Berkeley & USA & 1471 & 0.860 \\
University of Alaska Fairbanks & USA & 1431 & 0.837 \\
Yale University & USA & 1367 & 0.799 \\
Broad Institute of MIT and Harvard & USA & 1159 & 0.678 \\
University of California San Diego & USA & 1140 & 0.667 \\
Massachusetts Institute of Technology & USA & 1134 & 0.663 \\
University of Cambridge & England & 990 & 0.579 \\
University of Texas S/Western Medical Center Dallas & USA & 945 & 0.553 \\
University of Oxford & England & 838 & 0.490 \\
Scripps Research Institute & USA & 767 & 0.449 \\
Memorial Sloan Kettering Cancer Center & USA & 751 & 0.439 \\
California Institute of Technology & USA & 744 & 0.435 \\
University of California, San Francisco & USA & 709 & 0.415 \\
Wellcome Trust Sanger Institute & England & 695 & 0.406 \\
European Bioinformatics Institute & England & 671 & 0.392 \\
University of North Carolina & USA & 667 & 0.390 \\
Rockefeller University & USA & 639 & 0.374 \\
\hline
\end{tabular}

\section{(e) Contribution of Different Countries and Regions to Nature's IF for 2013}

The 2964 cited papers are from 48 countries and regions. The top 20 countries and regions that made the most outstanding contribution to Nature's IF for 2013 are shown in Table 6 along with their contribution values. The USA made the greatest contribution to Nature's IF for 2013, with a contribution value of 24.623, followed by England (4.236). The contribution rate of the USA and England to Nature's IF for 2013 comes to 70.4 percent indicating that the USA and England are important country sources for Nature. In addition, Germany, Japan, Switzerland, Canada, France, and China have also made large contributions to Nature's IF.

Table 6: Contribution of Different Countries and Regions to Nature's IF for 2013

\begin{tabular}{lcc||lcc}
\hline \multicolumn{1}{c}{ Country } & $\begin{array}{c}\text { Citation } \\
\text { counts }\end{array}$ & $\begin{array}{c}\text { Contribution to } \\
\text { IF }\end{array}$ & Country & $\begin{array}{c}\text { Citation } \\
\text { counts }\end{array}$ & $\begin{array}{c}\text { Contribution } \\
\text { to IF }\end{array}$ \\
\hline USA & 42106 & 24.623 & Spain & 813 & 0.475 \\
England & 7243 & 4.236 & Belgium & 717 & 0.419 \\
Germany & 4598 & 2.689 & Italy & 595 & 0.348 \\
Japan & 2278 & 1.332 & Sweden & 541 & 0.316 \\
Switzerland & 1974 & 1.154 & Israel & 430 & 0.251 \\
Canada & 1520 & 0.889 & Denmark & 395 & 0.231 \\
France & 1485 & 0.868 & Austria & 388 & 0.227 \\
China & 1309 & 0.765 & Scotland & 385 & 0.225 \\
Australia & 1031 & 0.603 & South Korea & 250 & 0.146 \\
Netherlands & 922 & 0.539 & Singapore & 233 & 0.136 \\
\hline
\end{tabular}




\section{CONCLUSIONS}

The study has taken Nature as a case to present a new method for calculating and analyzing the structure of the Impact Factor (IF) using the Web of Science (WoS) database and the definition of IF. We conclude that this computational method for journal IF is scientific and reasonable because firstly, the method for computing IF introduced in this paper strictly follows its original concept and calculation principle. Secondly, the data for predicting IF have the same source as the JCR database; all come from the WoS. Finally, we have also consulted the official technical service personnel from Thomson-Reuters regarding our computational method, and we received full confirmation of the method for the calculation of IF.

We have calculated the IF of Nature for the years 2008 to 2012 using the same method and compared them with their actual values (Table 1). The results of the comparison show that almost all of the calculated values are quite close to the actual values published by the JCR database, which supports the accuracy of our computational method from an empirical perspective.

The structural analysis of Nature's IF for 2013 shows that the contributions to IF of different document types differ greatly. The articles and reviews made the greatest contribution to Nature's IF for 2013, with a combined contribution rate of 93.94 percent; these earned more citation counts than other document types. In addition, although the number of editorial materials is slightly higher than the number of articles, their citation rate is far lower than that of the latter, demonstrating that it would be difficult to drastically improve a journal's IF by increasing the number of editorial materials only. Nevertheless, there could well be special cases for individual journals.

Through a structural analysis of the highly cited papers, authors, and institutions in Nature, we found that the magnitude of Nature's IF for 2013 is made up of the combined contributions from many highly cited papers, authors, and institutions, and that the highly cited papers, authors, and institutions are distributed relatively evenly. In other words, Nature is different from other journals in which few highly cited papers make a disproportionate contribution to the total number of citations (Liu 2014b), such as the Cancer Journal for Clinicians. This journal's IF for 2012 is 153.459; this high IF is derived mainly from the contributions of two papers written by A. Jemal (Jemal et al. 2010; Jemal et al. 2011), "Cancer statistics in 2010" and "Cancer statistics globally," in which the combined contribution rate is 70.9 percent.

Similarly, different countries and regions made entirely different contributions to Nature's IF for 2013; countries making the greatest contributions are mainly distributed in Europe, Asia, and America. The USA and England made the greatest contribution to Nature's IF, and the USA's contribution is well ahead of other countries. The differences in contributions to IF from different countries and regions remind us that we should pay close attention to the balanced development of global scientific research to promote academic exchange between different countries and regions.

\section{ACKNOWLEDGMENT}

Funding for this study was provided by the National Social Science Found of China (15BTQ061) and the Philosophy and Social Sciences Planning Project of Henan Province, People's Republic of China. 


\section{REFERENCES}

Adam, D. 2002. The counting house. Nature, Vol.415, no.6873: 726-729.

Andrade, A., González-Jonte R. and Campanario, J.M. 2009. Journals that increase their IF at least fourfold in a few years: the role of journal self-citations. Scientometrics, Vol.80, no.2: 517-530.

Betz, C.L. 2014. IF and other new developments. Journal of Pediatric Nursing-Nursing Care of Children \& Families, Vol. 29, no. 1: 1-2.

Campanario, J.M, Gonzalez, L. and Rodriguze, C. 2006. Structure of the IF of academic journals in the field of Education and Educational Psychology: citations from editorial board members. Scientometrics, Vol.69, no.1: 37-56.

Campanario, J.M. 2011a. Large increases and decreases in journal IFs in only one year: the effect of journal self-citations. Journal of the American Society for Information Science and Technology, Vol.62, no.2: 230-235.

Campanario, J.M. 2011b. Empirical study of journal IFs obtained using the classical twoyear citation window versus a five-year citation window. Scientometrics, Vol.87, no.1: 189-204.

Garfield, E. 1955. Citation indexes for science-new dimension in documentation through association of ideas. Science, Vol.122, no.3159: 108-111.

Garfield E. and Sher I.H. 1963. New factors in the evaluation of scientific literature through citation indexing. American Documentation, Vol.14, no.3: 195-201.

Holden, G., Rosenberg G., Barker K. and Onghena P. 2006. Should decisions about your hiring, reappointment, tenure, or promotion use the IF score as a proxy indicator of the impact of your scholarship? Medscape General Medicine, Vol.8, no.3: 21-21.

Jemal, A., Bray F. and Center M.M. et al. 2011. Global cancer statistics. Global cancer statistics, Vol.61, no.2: 69-90.

Jemal, A., Siegel R., Xu J.Q. and Ward, E. 2010. Cancer statistics, 2010. CA: a Cancer Journal for Clinicians, Vol.60, no.5: 277-300.

Jokic, M. 2003. Evaluation of Croatian journals covered by the ISI databases (Institute for Scientific Information). Periodicum Biologorum, Vol.105, no.1: 95-98.

Kim, M.J. and Kim B.J. 2000. A bibliometric analysis of publications by the Chemistry Department, Seoul National University, Korea, 1992-1998. Journal of Information Science, Vol.26, no.2: 111-119.

Liu, X.L. 2012. Correlation of publication frequency with IFs in 1058 medical journals in SClexpanded database. Malaysian Journal of Library \& Information Science, Vol.17, no.3: 716.

Liu, X.L. 2014a. Approach to predicting IF of SCI journals based on Web of Science database. Science-Technology and Publication, no.2: 87-91.

Liu, X.L. 2014b. Structural feature and enlightenment of the IF of 10 kinds of journals with authority internationally. Acta Editologica, Vol.26, no.3: 291-295.

Kovacic N. 2004. Structure of the 2003 IF for Croatian Medical Journal. Croatian Medical Journal, Vol.45, no.6: 671-673.

Pai, S.A. 2009. Nature, Elsevier voted the most influential journal, publisher in biology and medicine in past 100 years. National Medical Journal of India, Vol.22, no.4: 222-222.

Servaes, J. 2014. On IFs and research assessment. Telematics and Informatics, Vol.31, no.1: 1-2. 
Shao, J.F. and Shen H.Y. 2012. Research assessment and monetary rewards: the overemphasized IF in China. Research Evaluation, Vol.21, no.3: 199-203.

Simons, K. 2008. The misused IF. Science, Vol.322, no.5899: 165-165.

Ugolini, D and Casilli C. 2003. The visibility of Italian journals. Scientometrics, Vol.56, no.3: 345-355.

Vanclay, J.K. 2011. IF: outdated artefact or stepping-stone to journal certification? Scientometrics, Vol.92, no.2: 211-238.

Wu, X.F., Fu Q. and Rousseau R. 2008. On indexing in the Web of Science and predicting journal impact factor. Journal of Zhejiang University SCIENCE B, Vol.9, no.7: 582-590. 